\title{
Yankee Whaling in the Caribbean Basin: Its Impact in a Historical Context
}

\author{
Aldemaro Romero \\ Additional information is available at the end of the chapter
}

http://dx.doi.org/10.5772/50792

\section{Introduction}

Utilization of marine mammals in general and of whales in particular has varied greatly across historical periods and geographical locations. From prehistoric times (e.g., Stringer et al. 2008), the use of these animals was opportunistic by taking advantage of animals either beached (animals arrived dead on the coast) or stranded (animals arrived live on the coast). Later shore whaling (active whaling using small boats launched from the coast for a few hours) took place, and later came the development of industrial whaling, which engaged larger vessels embarked in whaling expeditions that might have lasted up to several years at a time. The heyday of industrial whaling took place during the mid-nineteenth century and was epitomized by Yankee whaling (Sanderson 1993).

For the purposes of this chapter, I define Yankee whaling as an offshore fishery carried out by American whaling vessels between 1712 and 1925 (Starbuck 1876, p. 20; Hegarty 1959, p. 47). The geographical area considered as Caribbean Basin for the purpose of this chapter is defined as all the coasts (clockwise) of Venezuela, northern Colombia, eastern Central America, the Yucatán Peninsula, and all of the coasts of the Antilles from Cuba down to Trinidad including the Bahamas and Bermuda. The Bahamas are commonly included as part of the Caribbean Basin from a geological and cultural viewpoint. Bermuda, although being geographically an oceanic island in the western North Atlantic, has cultural ties to many of the Caribbean Basin countries including being the springboard for numerous whaling operations in the region (Romero 2006).

The aim of this chapter is to describe Yankee whaling in the Caribbean Basin in a historical context to understand its development, cultural, and ecological impact. 


\section{Methods}

As a general source of data on Yankee whaling expeditions I used Lund (2001). Of the known 14,864 voyages of Yankee whalers there were at least 1101 voyages to the North Atlantic of which 454 were voyages to the Caribbean Basin (including Bermuda). Many of those voyages included whaling operations in more than one location in the Caribbean. All information about those voyages was tabulated by vessel name, year of departure, and locality visited. Many of the logbooks of the vessels involved in this activity were examined at the New Bedford Whaling Museum, the Free Public Library, New Bedford, and the Providence Public Library. Other information of this activity for this area was compiled from numerous sources cited throughout this chapter.

\section{Quantitative results}

The places visited by Yankee whalers and the numbers of visits per locality are shown in Figure 1. Barbados and Bermuda are the places most visited by Yankee whaling vessels.

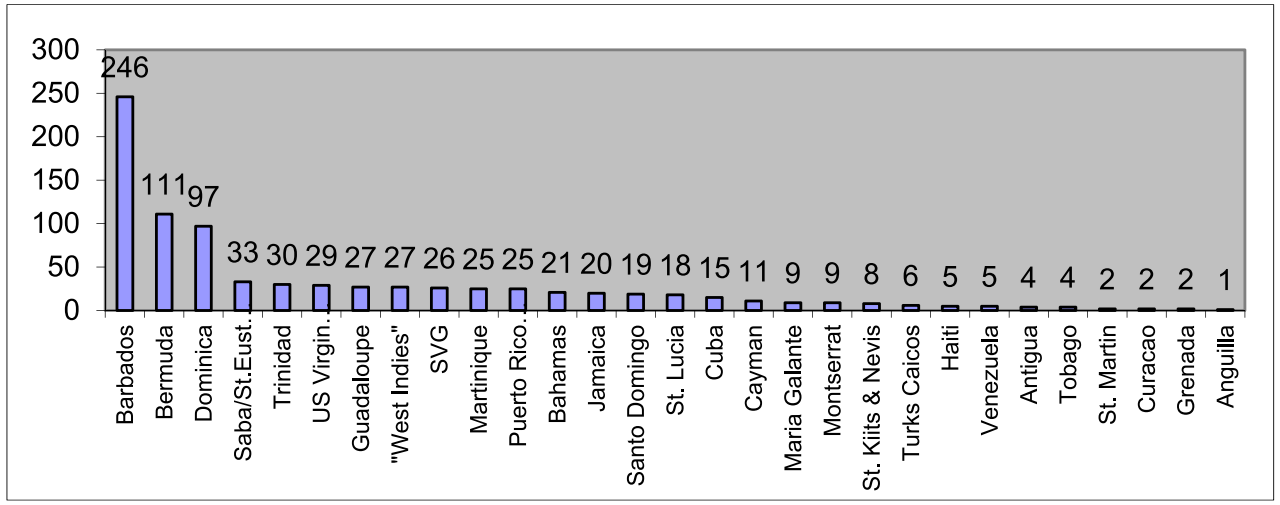

Figure 1. Places visited by Yankee whalers and their frequency.

The frequency with which that activity took place is shown in Figure 2. To that figure other historical information was added in order to put the activity in historical context. That context is interpreted in the Discussion section.

I combined this information with other historical records of the political, economic and social circumstances that might have influenced whaling in that geographic area. This chapter shows how a holistic description of a whaling activity requires understanding of the interplay among numerous factors.

\section{Historical narrative of marine mammal exploitation in the Caribbean Basin}

Native Americans exploited cetaceans and other marine mammals in the Caribbean Basin since before the arrival of the Europeans (Acosta 1590, Romero et al. 1997, Romero and 
Hayford 2000, Romero et al. 2002). The first whaling operations in this area, as defined earlier by Europeans or people of European descent, were in Bermuda. As soon the first English colonists arrived in those islands in 1609 they tried to hunt humpback whales (Megaptera novaeangliae) but it was not until 1663 when the first successful attempt took place in those waters (Romero 2006).

The earliest record of an attempt to whale in the Caribbean Basin area by New Englanders was in 1688 when there was a petition to the Governor of New York asking for permission to carry on "a fishing Design about the Bohames Islands and Cap florida for sperma Coeti whales and Racks: And so to returned for this Port" (Starbuck 1876, p. 15). The term "sperma Coeti" refers to the sperm whale (Physeter macrocephalus) and "Racks" was a spelling used in the seventeenth century for wrecks. Although there is no record that this expedition ever took place, this is an interesting record because it is dated 24 years before the first actual successful hunt of a sperm whale took place by New Englanders in 1712 near Nantucket (Hawes 1924, p. 57).

The earliest known logbook that refers to a successful Yankee whaling expedition to the Caribbean Basin is that of Two Brothers, from Nantucket, MA. This brig visited Barbados in 1775 (logbook at the New Bedford Whaling Museum under the former collection of the Kendall Whaling Museum). The last one was of the schooner Athlete out of New Bedford that visited St. Thomas in 1921. Yet, there are indications that some Yankee whalers had been visiting the area for many years before that (Clark 1887, p. 64-65) (see Table 1).

\begin{tabular}{|l|l|l|}
\hline \multicolumn{1}{|c|}{ Year } & \multicolumn{1}{c|}{ Locality } & \multicolumn{1}{c|}{ Source(s) } \\
\hline 1730 's & Bahamas & Sanderson 1993, pp. 212-213 \\
\hline $1750-1784$ & Bahamas & Tower 1907, p. 33 \\
\hline 1762 & "French West Indies" & Starbuck 1876, p. 41 \\
\hline 1762 & "Bermuda Ground" & Stackpole 1953, p. 50, Lund 2001, p. 651 \\
\hline 1762 & Barbados & Stackpole 1953, p. 51 \\
\hline 1763 & Barbados & Stackpole 1953, p. 23 \\
\hline 1768 & “West Indies" & Stackpole 1953, p. 48-49 \\
\hline 1775 & St. Eustatius, Barbados & Stackpole 1953, p. 73 \\
\hline
\end{tabular}

Table 1. Sources of earlier visits of the Caribbean Basin by American whaleships.

Although occasional expeditions also took place primarily between 1830 and 1860, the heyday of Yankee whaling in the Caribbean Basin occurred roughly between 1860 and 1880. Below is the narrative of how Yankee whaling interplayed with the majority of the countries visited.

\subsection{Barbados}

American whaling vessels frequently visited Barbados. This island has the largest number of visits registered in this study. Yankee whalers engaged in whaling and the trans-shipment of whale oil and utilized Barbadian ports for the re-stocking of provisions. Additionally, 
some Yankee whaling vessels were taken there after being captured by British vessels during the British-American War (1812-1815); others were simply abandoned there. This provided ample opportunity for Barbadians to have direct contact with whalers and to acquire whaling skills. For example, an unspecified number of locals joined Yankee whaling vessel crews in order to fulfill the need for hands on board because of death and desertion. Since Yankee whalers recruited many Barbadians, they gained the necessary skills to hunt whales they later applied to shore whaling after returning to Barbados. The combination of Yankee and shore whaling led to the local extinction of humpback whales in those waters (Romero and Creswell 2010 and references therein).

\subsection{Bermuda}

There are very few traces of intense contact between Bermudans and Yankee whalers. That was due to a combination of factors: (1) Bermuda was a stronghold of the British during the Revolutionary War, which made its waters off-limits to New Englanders; (2) during the British-American war of 1812, the English utilized Bermuda as a major base for their naval operations and any American vessel in those waters (whaler or otherwise) was captured and taken there; (3) during the American Civil War Bermudans who had historical ties with the South, particularly Virginia and the Carolinas, sided with the confederates, making of Bermudan waters hostile territory to Yankee whalers and (4) by the time of the heyday of Yankee whaling the local populations of humpbacks were already severely depleted since shore whaling began around 1663 in those waters.

Thus, despite the overall large number of Yankee whalers visiting Bermuda, it seems that those visits were more a matter of convenience for obtaining provisions for ships either heading to the Eastern Atlantic grounds or heading south to the Caribbean. My survey of archival material in Bermuda yielded no information about relationships between Yankee whalers and the locals (Romero 2009).

\subsection{Trinidad and Tobago}

Activities by Yankee whaling ships for Trinidad and Tobago have been summarized elsewhere (Romero et al. 2002). All indications are that there was never much interaction between Yankee and land-based whalers. Yankee whaling in the area did not start until the 1830s, when their Trinidadian counterparts were already fully engaged in whale hunting. If anything, Yankee whaling may have furthered the whale population decline since humpbacks are virtually extinct in that area at the present time.

\subsection{St. Vincent and the Grenadines (SVG)}

Yankee whalers began whaling in the waters of SVG in the early 1800's and their activity peaked in 1864. They hunted humpback, sperm, and short-finned pilot whales (Globicephala macrorhynchus). Both pilot and humpback whales were chosen as target species because of the seemingly abundant populations and the products that can be 
extracted from them. Humpback whales produce a high volume of oil (approximately 25 barrels per adult animal), whereas pilot whales produce two types of oils: one from the blubber and one from the melon (a bulbous area located on the head of the animal). Oil from the latter is of high quality as characterized by its ability to retain stable physical/chemical properties under conditions of extreme temperature and pressure. This oil was used to lubricate precision instruments and was exported to the United States. In addition, local residents utilized the oil from both species as well as other body parts for either human consumption of the meat or for the manufacturing of some goods. Sperm whale hunting did not persist because the demand for its oil declined and the meat was considered inedible. In addition, local fishermen found that sperm whales were difficult and dangerous to catch.

From archival records there were 25 were voyages to SVG for whaling, that took place between 1864 and 1886. In the 10 logbooks I examined 196 entries (daily records kept by the captain or designated crew member) regarding whale hunting. These entries documented that Yankee whalers sighted whales and lowered their boats 117 times. Of those attempts, $34.2 \%$ were successful at harpooning one or more humpback whales, but only 40 whales were landed. At least six of those landings were mother/calf pairs. Nine whales were hit but lost. With the addition kill/loss correction factor, Yankee whalers killed an estimated 75 humpback whales between 1864 and 1871.

The local residents adopted boat designs and equipment from Yankee whalers for shore whaling. In addition, terminology of the Yankee whalers such as 'sea-guaps' for sperm whales and 'blackfish' for short-finned pilot whales are names still used locally today. Cultural influence on SVG whalers by Yankee whalers can also be seen in the transfer of New England whaling shanties, or songs that helped the whalers keep rowing rhythm (Kannada 2006 and references therein).

\subsection{St. Lucia}

This island was occasionally visited by Yankee whalers and sometimes was used as a base for their whaling. These vessels mostly pursued humpbacks, but occasionally took some short-finned pilot whales (Reeves, 1988). The last report of Yankee whaling for St. Lucia is dated 1883 (Reeves and Smith, 2002).

\subsection{Grenada}

The presence of Yankee whalers was not uncommon in Grenadian waters during the second half of the nineteenth century. In the early months of 1857 as many as eight American whalers might have been seen anchored off St. George's, Grenada's capital, with their boats fully employed. Whaling ships primarily hunted humpbacks, but occasionally landed sperm whales, and a high percentage of their catch was cow-calf pairs. The ships provided whale meat to the local market of Grenada and the neighboring southern Grenadines (Romero and Hayford, 2000, and references therein). 


\subsection{Venezuela}

Yankee whalers visited the area of the Gulf of Paria, between Venezuela and Trinidad, between 1837 and 1871 but may also have visited other localities and at other times. They predominantly hunted humpbacks, but occasionally they would strike a sperm whale or a 'blackfish,' (G. macrorhynchus). Yankee whalers also visited other coastal areas in eastern Venezuela. Since data are incomplete, the only quantitative statement I can make, based on the summary provided by Reeves et al. (2001), is that Yankee whalers, captured at least 25 whales, during at least nine whaling voyages. There was very little, if any, interaction between the whaling crews and Venezuelans. Therefore, there is no evidence that they ever influenced any marine mammal exploitation practice in Venezuela. Further, the presence of Yankee whaling ships created some stir in the local press, because the locals saw this operation as a breach of their national sovereignty (Romero et al 1997 and references therein).

\section{Discussion}

Fig. 2 shows Yankee whaling activity based on tonnage (blue line), number of trips to the Caribbean Basin (red line), and the historical factors that contributed to the fluctuation in the intensity of Yankee whaling overall. The first noticeable aspect between Yankee whaling activities in general with that in the Caribbean Basin is the asynchrony between the two. While Yankee whaling intensity reached a peak between the U.S. industrial boom of the 1830s and the industrial exploitation of mineral oil in the early 1860s, the expansion of the Yankee whaling activity in the Caribbean Basin took place between the mid 1860's and the mid 1870s. Therefore we need to examine economic factors to understand this phenomenon.

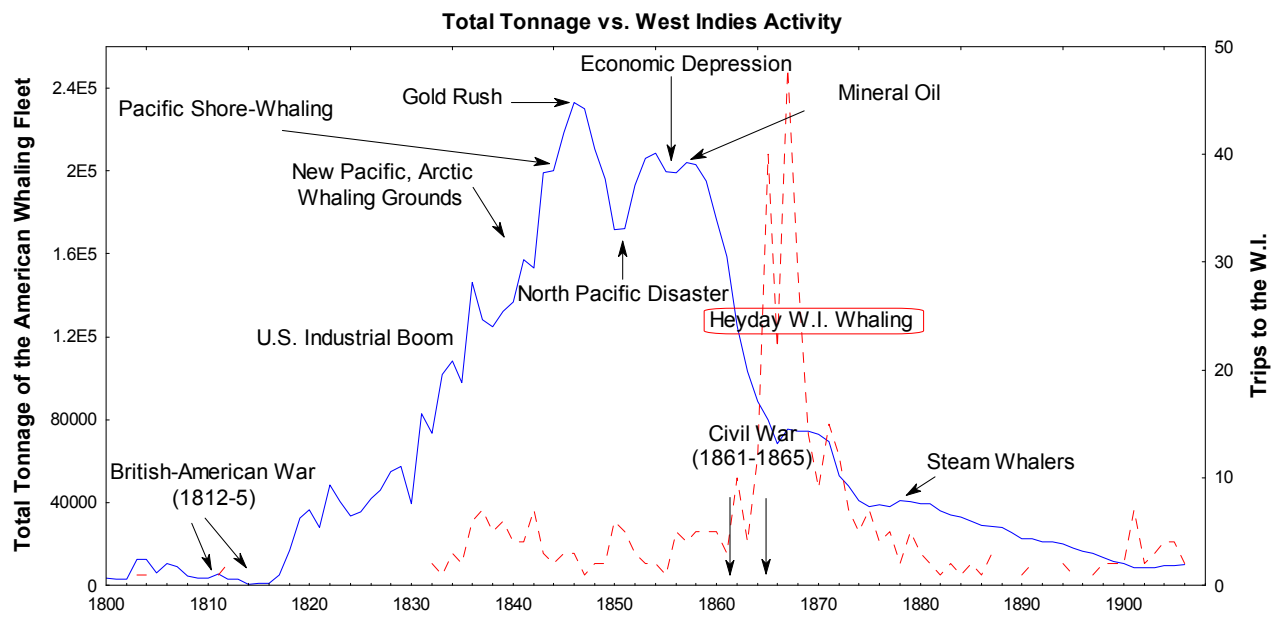

Figure 2. Total activity of Yankee whaling by tonnage (blue line) and by number of trips to the Caribbean basin (red line). There is an asynchrony between the two suggesting that the Yankee whaling activity in the West Indies was a marginal operation that took place after the traditional whaling grounds had been depleted. Arrows represent historical events to give a context to better understand how political and economic factors influenced these activities in general. 
First we need to recognize that Yankee whalers shifted both whaling grounds and species targets as resourses became scarcer in different geographic areas. Romero and Kannada (2006), using historical catch records, report that populations of bowhead (Balaena mysticetus) and right whales (Eubalaena glacialis) in the North Atlantic became severely depleted by the $19^{\text {th }}$ century. This depletion caused Yankee whalers to seek new hunting grounds in the Caribbean. Yet that happened shortly after substitute products such as kerosene and mineral oil became available in the market making. As a consequence the demand for whale oil declined as soon as subsurface mineral oil was discovered at Titusville, Pennsylvania, in 1859 (Coleman 1995). Although there was again an increase in the price of whale oil during the American Civil War (1861-1865) due to increased demand, whale oil prices declined severely after that.

The Yankee whale oil industry responded by trying to lower their production costs that were becoming higher as their vessels had to navigate to more difficult grounds. To that end they tried to make their operations more efficient by improving whaling technology with the introduction of the exploding harpoon head in 1864 and by reducing labor costs by hiring more and more crews from countries in the Caribbean Basin, particularly Englishspeaking ones. By this time, whalers were earning one-third to one-half of what merchant seamen earned and one-fifth of a shore laborer (Coleman 1995).

Thus a combination of the depletion of whale stocks in the historical whaling grounds of the North Atlantic together with lower labor costs by hiring natives from the West Indies shifted Yankee whaling activities to the Caribbean basin (and later to Artic and Antarctic waters). As Brandt (1940, p. 54) put it "Slowly the crews had to be composed more and more of halfcastes from all parts of the West Indies and of Central and South America."

These circumstances increased interaction between Yankee whalers and West Indies locals, which led to both technology transfer to the countries they were recruiting crews and depletion of local populations of whales, particularly humpbacks. Yet, the cultural influence of Yankee whalers on that part of the world was uneven. The large number of voyages to Barbados and Bermuda may be due not only to the presence of whales in those waters, but also because (1) Barbados is the first island a ship traveling from the east Atlantic encounters when sailing with the aid of the trade winds and (2) Bermuda is the only island between the North American continent and other whaling grounds in the eastern Caribbean such and Cape Verde.

Yet, by the time Yankee whalers initiated a significant activity in the Caribbean Basin, two localities -both under British sovereignty at that time: Bermuda and Trinidad and Tobago has already developed a local shore whaling industry: Bermuda in 1663 (Romero 2006) and Trinidad in the 1820's (Romero et al., 2002). This contradicts the generalization made by Caldwell \& Caldwell (1971) that Yankee whalers directly influenced shore whaling in the Caribbean.

Yankee whaling activity in Trinidad and Tobago have been summarized elsewhere (Reeves et al., 2001, Reeves and Smith, 2002). All available data indicate that there was never much interaction between Yankee and the already established shore whaling industry of Trinidad. Yankee whaling in the area did not start until the 1830s, when Trinidadian shore whaling was already in full swing. In fact, the owners of one of the whaling stations in Trinidad asked the Governor of the Island to refuse authorization for the American Schooner 
Harmony, of Nantucket, to whale in the Gulf of Paria, for fear of competition (de Verteuil, 1994). It is not known how the Governor decided in this matter. Still some Yankee whaling vessels continued occasionally visiting Trinidad's waters until at least 1867 . There are records of Yankee whaling ships visiting Tobago waters during 1877, although it is unclear whether or not they actually captured any whales (Reeves and Smith, 2002).

Yet, in other places such as SVG, the story was different. Despite the fact that the number of voyages by Yankee whalers these and other surrounding islands was relatively low in comparison to those to Bermuda and Barbados, their cultural influence in undeniable. For example, a SVG resident named William Wallace took interest in whaling and participated as a crewmember on several Yankee whaling expeditions. He later left Bequia and moved to New Bedford, Massachusetts, the center of the Yankee whaling fleet. While in New Bedford, he learned whaleboat design, tool production and maintenance, and hunting methods. Upon returning to SVG, he applied this new knowledge and began whaling. Whaling represented an opportunity for economic development for men of European ancestry returning to an impoverished island. Thus, the development of the whaling industry in SVG was the result of cultural contacts rather than a direct correlation of intensity of Yankee whaling operations in those waters (Kannada 2006).

The reason why Yankee whalers did not intensively exploit whales in SVG had to do with yield per unit of effort. The efficiency with which Yankee whalers caught whales in SVG was less than ideal: $38.5 \%$ success rate (killing and hauling in). This was probably due to the limitations of the boats, which were rowboats, and the inaccuracy of hand-thrown harpoons. It seems that landing a humpback whale was a difficult task. These same limitations may have played a role in Yankee whaler's choice not to hunt pilot whales unless times were desperate. In contrast to the large, slow moving, and obvious humpback whales; the shortfinned pilot whales are small and quick. Chasing after the smaller and faster pilot whales would have been extremely costly in terms of time and profit potential (Kannada 2006).

Prior to the 1986 International Whaling Commission (IWC) moratorium on commercial whaling, SVG and the rest of the world for that matter, whaled without regard to depletion issues. Despite a negative correlation between global oil value and the number of humpback whales caught in SVG, it is unlikely that the global market drove the industry. SVG exported oil and meat of humpback whales to neighboring countries in only small quantities. It is more likely that the persistence of the humpback whale fishery in SVG was due to local tradition and local demand for whale products as there are no longer exports of these products outside the country. The SVG market followed the typical supply and demand curve in that as the amount of humpback whale oil became available, the less it cost which lead to a higher demand for the product. Since the late 1930's, there has been little fluctuation in the number of humpback whales killed and that number has remained low (no more than 4 killed in any one year) (Kannada 2006).

\section{Conclusions}

The intensification of Yankee whaling in the Caribbean was due to a combination of factors such as (1) depletion of stock whales in traditional whaling grounds of the North Atlantic 
and (2) higher costs of whaling which led to the search of lower labor costs by hiring crews in the West Indies, particularly given that wages for crews of merchant vessels and shore industries were higher.

The discovery and development of a replacement commodity (mineral oil) together with the increase risks of investment on the whaling activity due to longer and longer voyages would ultimately signify the end of whale oil as a major commercial commodity.

The bulk of Yankee whaling in the Caribbean Basin was short-lived and out of sync with the heyday of Yankee whaling. It concentrated in the southeastern Caribbean most likely because of the abundance of humpback whales in that area. The cultural influence of Yankee whalers varied by location mostly determined on whether or not their arrival took place before the development of local shore whaling. Therefore, a combination of factors, including whale stocks, political events, and labor and other economic and social issues influenced Yankee whaling activities in the Caribbean.

Both Yankee whaling and local shore whaling led to the depletion of humpbacks in the Caribbean Basin as it has been quantified elsewhere (Swartz et al. 2003, Smith and Reeves 2003).

\section{Author details}

Aldemaro Romero

College of Arts and Sciences, Southern Illinois University Edwardsville, Peck Hall, Edwardsville, IL, USA

\section{References}

Acosta, J. de. 1590 (1940). Historia Natural y Moral de las Indias. Fondo de Cultura Económica. México.

Brandt, K. 1940. Whale oil. An economic analysis. Stanford University.

Caldwell, D. K. and Caldwell, M. C. 1971. Porpoise fisheries in the southern Caribbean present utilizations and future potentials. In Proceedings of the $23^{\text {rd }}$ Annual Session of the Gulf and Caribbean Fisheries Institute, Higman, J. B. (ed.), Rosenstiel School of Marine and Atmospheric Science: Coral Gables, FL; 195-206.

Clark, A. H. 1887. The whale-fishery. 1. History and present condition of the fishery. In The Fisheries and Fishery Industries of the United States, Section V, Volume II, History and Methods of the Fisheries, Goode, G. B (ed.), U.S. Government Printing Office: Washington, D.C.; 3-218.

Coleman, J.L. 1995. The American whale oil industry: a look back to the future of the American petroleum industry? Natural Resources Research 4(3):273-288.

de Verteuil, A. 1994. The Germans in Trinidad. Port-of-Spain: The Litho Press.

Hawes, C.B. 1924. Whaling. New York: Doubleday, Page and Company.

Hegarty, R.B. 1959. Returns of whaling vessels sailing from American ports. New Bedford: The Old Dartmouth Historical Society.

Kannada, S.D. 2006. Environmental history and current practices of marine mammal exploitation in St. Vincent and the Grenadines, W.I. MS Thesis. Jonesboro, AR: Arkansas State University. 
Lund, J.N. 2001. Whaling masters and whaling voyages sailing from American ports. A compilation of sources. New Bedford, MA: New Bedford Whaling Museum.

Reeves, R.R. 1988. Exploitation of cetaceans in St. Lucia, Lesser Antilles, January 1987. Report of the International Whaling Commission 38:445-447.

Reeves, R.R. and T.D. Smith. 2002. Historical catches of humpback whales in the North Atlantic Ocean: an overview of sources. Journal of Cetacean Research and Management 4(3):219-234.

Reeves, R.R., Swartz, S.L., Wetmore, S. and Clapham, P.J. 2001. Historical occurrence and distribution of humpback whales in the eastern and southern Caribbean Sea, based on data from American whaling logbooks. Journal of Cetacean Research and Management, 3: 117-129.

Romero, A. 2006. "More private gain than public good": whale and ambergris exploitation in seventeenth-century Bermuda. Bermuda Journal of Archaeology and Maritime History 17 (in press).

Romero, A. 2009. Chasing fools' gold: whaling in $19^{\text {th }}$ and $20^{\text {th }}$-century Bermuda. Bermuda Journal of Archaeology and Maritime History 19: 141-163.

Romero, A.; I. Agudo \& S. Green. 1997. Cetacean exploitation in Venezuela. Reports of the International Whaling Commission. 47:735-746.

Romero, A., R. Baker, J. E. Creswell, A. Singh, A. McKie \& M. Manna. 2002. Environmental history of marine mammal exploitation in Trinidad and Tobago, W.I. and its ecological impact. Environment and History 8(3):255-274.

Romero, A. \& J.E. Creswell. 2010. Deplete locally, impact globally: environmental history of shore-whaling in Barbados, W.I. The Open Conservation Biology Journal 4:19-27.

Romero, A. \& K. Hayford. 2000. Past and Present Utilization of Marine Mammals in Grenada. Journal of Cetacean Research and Management 2(3):223-226.

Romero, A. \& S.D. Kannada. 2006. Comment on “Genetic analysis of 16th-century whale bones prompts a revision of the impact of Basque whaling on right and bowhead whales in the western North Atlantic". Canadian Journal of Zoology 84:1059-1065.

Sanderson, I.T. 1993. A history of whaling. New York: Barnes \& Noble.

Smith, T.D. and R.R. Reeves. 2003. Estimating American 19(th) century catches of humpback whales in the West Indies and Cape Verde Islands. Caribbean Journal of Science 39:286-297.

Stackpole, E.A. 1953. The Sea-Hunters. The New England Whalemen during two centuries 1635-1835. Philadelphia: J.B. Lippincott Co.

Starbuck, A. 1876 (1989). History of the American Whale Fishery from its earliest inception to the year 1876. Reprinted by Castle Books, Secaucus, NJ.

Stringer, C.B.; J. C. Finlayson, R. N. E. Barton, Y. Fernández-Jalvo, I. Cáceres, R. C. Sabin, E. J. Rhodes, A. P. Currant, J. Rodríguez-Vidal, F. Giles-Pacheco \& J. A. Riquelme-Cantal. 2008. Neanderthal exploitation of marine mammals in Gibraltar. Proceedings of the National Academy of Sciences (USA) 105:14319-14324.

Swartz, S.L., T. Cole, M.A. McDonald, J.A. Hildebrand, E.M. Oleson, A. Martinez, P.J. Clapham, J. Barlow and M.L. Jones. 2003. Acoustic and visual survey of humpback whale (Megaptera novaeangliae) distribution in the eastern and southeastern Caribbean Sea. Caribbean Journal of Science 39:195-208.

Tower, W.S. 1907. A history of the American whale fishery. Philadelphia University of Pennsylvania. 